\title{
Cassava Genotype Evaluation for Grasshopper Zonocerus variegatus (L.) (Orthoptera: Pyrgomorphidae) Susceptibility in Southern Sierra Leone
}

\author{
A. Mansaray ${ }^{1}$, A. J. Sundufu ${ }^{2, *}$, A. E. Samura ${ }^{1}$, F. B. Mass aquoi ${ }^{1}$, D. D. Quee ${ }^{1}$, S. N. Fomba ${ }^{1}$, \\ M. T. Moseray ${ }^{1}$
}

${ }^{1}$ Sierra Leone A gricu ltural Research Institute, Njala, Sierra Leone
${ }^{2}$ Department of Biological Sciences, Njala University, Njala, Sierra Leone

\begin{abstract}
Reports of damage by grasshopper Zonocerus variegatus (L.) to cassava and other crops has increased in recent years. The attack on cassava is particularly threatening to the livelihood of many poor subsistence farmers in Sierra Leone. As such, an evaluation was conducted to investigate the use of host plant resistance as an alternative method of managing grasshopper rather than the sole reliance on chemicals. The experiment was laid out in a randomized complete block design with three replications. Two blocks were used (protected and unprotected) with twenty cassava varieties (Slicass 1 05-21, VT 05-02, Slicass 2, SN 05-22, Slicass 1 05-14, Slicass 2 05-17, Slicass 5, VT 05-07, SN 05-41, Slicass 1 05-05, 97/3202-05-04, Slicass 4, Slicass 1 05-42, SN 05-17, Slicass 1, Local, 97/0057-05-04, Slicass 6, 97/0057-05-01 and Slicass 2 05-13) in each block. Pest assessments was done at 3, 6, 9 and 12 Months After Planting (MAP) which coincides with the various seasons; rain, dry and dry-rainy transition periods. Significant differences were recorded in percentage incidence and severity score with respect to cassava variety and time of observation. While seven cassava varieties (Slicass 5, VT05-02, Slicass 4, 97/0057-05-04, 97/0057-05-01, slicass 6 and Slicass 105-21) were found to be less susceptible to $Z$. variegatus (L.), four varieties (Slicass 2 05-17, Slicass 1 05-41, Slicass 2 05-13 and 97/005-05-04) out yielded (in terms of tuber weight and number) the released varieties during the two cropping seasons. Percent incidence and severity score was relatively high at 6MAP and 9MAP. Overall, tuber weight and number were higher in the protected plot compared to the unprotected plot during the two cropping seasons. Hence, protecting cassava field from grasshopper infestation may increase yield, number of tubers and invariably the production of good quality planting material that is resistance to grasshopper attack.
\end{abstract}

Keywords Genotype, Zonocerus Variegatus, Susceptibility, Cynogenic Glucoside

\section{Introduction}

Cassava (Manihot esculenta Crantz) is the most important tuberous root crop and the second most important food crop after the staple crop, rice. Cassava has increasingly become a strategic commodity for Sierra Leone food economy; as consumption has expanded beyond the traditional rural production zones into the growing towns and cities of the country. Insect pests perhaps constitute the greatest constraints to cassava production in Africa as in [1], causing an estimated $50 \%$ root yield reduction. The yield losses vary with the pests and the prevailing climatic conditions as reported in[2]. Of the insect pests that attack cassava in Sierra Leone, the variegated grasshopper Zonocerous variegatus (L.) is one of the important pests the causes

* Corresponding author:

jasundufu@gmail.com (A. J. Sundufu)

Published online at http://journal.sapub.org/ijaf

Copyright (C) 2012 Scientific \& Academic Publishing. All Rights Reserved considerable yield loss in the cassava growing regions of the country.

The variegated grasshopper ( $Z$. variegatus $(\mathrm{L})$ ) is a voracious and destructive insect, native to the humid forest zone of West Africa[3]. It belongs to the same order (Orthoptera) as locusts. This insect can defoliates and destroys the stem bark of food crops at the end of the dry season. The feeding behaviour of this pest also results in the reduction in cassava tuber quality and the destruction of cassava cuttings [4],[5].

Although often viewed as a polyphagous pest, grasshoppers are selective to some degree, exhibiting definite plant preferences[6]. Studies carried out by[7] have shown that grasshoppers could be conveniently classified as grass-feeders (Graminivorous), forb-feeders (forbivorous) or a mixture of the two (ambivorous or mixed feeders). Also,[8] have attributed the chemical composition of plants as the main factor in the food selection behaviour of grasshoppers. 
Res earch has shown that early nymphs of grasshoppers are deterred from feeding on cassava due to the presence of cynogenic glucosides[9]. The concentration of this secondary plant compound varies among cassava clones ( 80 to $167 \mathrm{mg} \mathrm{CN}$ per $100 \mathrm{~g}$ of fresh leaf)[3].

Control of the variegated grasshopper has generally involved Knock off' che mical pesticides. However, because of the increasing concern of its effect on non-target organisms, prohibitive cost and persistence in the environment, there is the need for environmentally friendly alternative. In this light, host plant resistance could be adopted as an alternative means to the control of grasshoppers. Host plant resistance can be described as any reduction in the population growth of a target pest as influenced by inheritable characteristic of the host plant compared to a standard variety[10]. Host plant resistance is as a result of the presence of secondary compounds found in plants; the nature and concentration of these compounds varies in time and space and also among and within plant varieties [8].

The knowledge of host plant resistance against certain pests can help farmers in screening for resistance varieties. More over, knowledge of the degree of susceptibility of different cultivars can aid in detecting and monitoring pest population. Also, stability in yields of agronomically desirable and commercially acceptable cultivars is the ultimate goal in cassava improvement and a pre-requisite in achieving sustainability. One way to ensure this is to select cultivars with adequate levels of resistance to pests. These relatively resistance cultivars could be recommended to farmers for adoption. Adoption of such varieties will increase yield leading to increase in farmers' income.

The objectives of this study are two fold:

(a)Field screening of twenty cassava genotypes with the aim of identifying promising genotypes that are less susceptible to gras shoppers.

(b)Assessing yield loss due to grasshopper feeding.

\section{Materials and Methods}

\subsection{Location of Field Trials}

This trial was conducted during two cropping season (2009/2010 and 2010/2011)at the Njala Agricultural Research centre (NARC) experimental Site, Njala. Njala is situated at an elevation of $50 \mathrm{~m}$ above sea level in $8 \circ 06^{\prime} \mathrm{N}$ latitude and $12 \circ 06^{\prime} \mathrm{W}$ longitude. There are two distinct seasons, the wet season (May-October) and the dry season (November-April). Mean annual rainfall at Njala is $2525 \mathrm{~mm}$; mean monthly maximum air temperature range fro $\mathrm{m} 29^{\circ} \mathrm{C}$ to $23^{\circ} \mathrm{C}$. Relative humidity is very high often close to $100 \%$ for the greater part of the day and night especially during the rainy season[11]. During the dry seas on potential evapo-transpiration exceeds rainfall while during the rainy season precipitation exceeds evapo-transpiration. The predominant vegetation at $\mathrm{Njala}$ is secondary bush and the soils belong to the Njala series (Orthoxic palehumult).
Textures are usually gravelly clay loam in the surface and gravelly clay loam to gravelly clay in the sub-soil. The soils are low in soil mo isture and have a very low nutrient status and are slightly acidic with $\mathrm{pH}$ ranging fro $\mathrm{m} 5.5$ to 6.0 [11].

\subsection{Experimental Design}

The field trial was conducted on twenty cas sava genotypes including all released varieties. Selection of genotypes was made based on morphology, petiole colour, y ield and taste. The local variety cocoa was used as check. Insect pest free cassava stem cuttings of $20 \mathrm{~cm}$ in length obtained from 12 month-old mother plants at the middle part of the stem was used.

A randomized complete block design with three replications was used. Each plot measured $40 \mathrm{~m}^{2}$ (4m x 10m) and contain four ridges $10 \mathrm{~m}$ long and $1 \mathrm{~m}$ apart. Planting was done on the $16^{\text {th }}$ July during the 2009/ 2010 cropping seas on and on the $20^{\text {th }}$ July during the 2010/2011 cropping season. Two blocks were used. Block A (unprotected plot) was located closer to the source of grasshoppers infestation. Block B (protected plot) on the other hand, was located in an area that is less prone to grasshoppers. This plot was sprayed with malathaion to kill the nymphs and adults that initially infested the field. Hand picking was also done regularly in the protected plot to prevent grasshopper infestation throughout the growing season.

\subsection{Data Collection and Analysis}

Evaluation of the genotypes for susceptibility to grasshopper in the field was based on the injury done to each genotype by the pest. Grasshopper severity was estimated using the visual rating scale of $1-5$ per individual plant; where: $1=0-20 \%$ of foliage consumed, $2=21-40 \%$ of foliage consumed, $3=41-60 \%$ of foliage consumed, $4=61$ - $80 \%$ of foliage consumed and $5=81-100 \%$ of foliage consumed as in[12].Pest assessments was done at 3, 6, 9 and 12 Months After Planting (MAP) which coincides with the various seasons; rain, dry and dry-rainy transition periods. Percentage incidence was expressed, as the number of infected cassava stand over the total number of cassava stands sampled. Severity was expressed as the total area of the cassava plant tissue affected over the total area of the plant tissue.

Data on plant damage was collected on the two middle rows per plot, which at maturity was used for yield estimation.

Yield estimate per genotype (number and tuber weight) was done at the end of the growing seas on from each block by harvesting 16 central plants of each genotype. Hand weeding was done as and when necessary.

All data collected were subjected to two-way ANOVA and means were separated using the Student Newman Keuls Test (SNK) at 0.05 level of significance[13].

\section{Results and Discussions}




\subsection{Percentage Inci dence}

Analysis using ANOVA reveals significant differences in percentage incidence of grasshopper with respect to cassava variety during the $2009 / 2010(\mathrm{P}=0.0001, \mathrm{~F}=26.56)$ and $2010 / 2011(P=0.0001, F=3.56)$ cropping seasons. The reason for this difference could be related to genetic differences among the cultivars used. Cassava is known to produces a noxious cynogenic glucoside which deters feeding by grasshopper. The concentration of this secondary plant compound varies among cassava clones (80 to $167 \mathrm{mg}$ $\mathrm{CN}$ per $100 \mathrm{~g}$ of fresh leaf)[3]. Reference[8] have attributed the chemical composition of plants as the main factor in the food selection behaviour of grasshoppers.

Percentage incidence was generally low during the 2009/2010 cropping season with the local variety recording the highest incidence $(29.76 \%)$ whilst Slicass $105-14$ recorded the least $(8.91 \%)$ (Table 1). On the other hand, percentage incidence during the 2010/2011 cropping seas on ranged from moderate $(45.16 \%)$ to low $(10.42 \%)$ with again the local variety registering the highest incidence whilst VT 05-02 recorded the least incidence. Generally, percentage incidence was significantly $(\mathrm{P}<0.05)$ higher during the 2010/2011 (24\%) cropping season compared to 2009/2011 cropping season $(16 \%)$ (Table 1). The reason for this variation between to the cropping seasons could probably be due to variation in chemical composition of the cassava genotypes with season. This observation is in agreement with the findings of[14]. This author reported that the concentration of secondary compound in plants changes along the year or along growth season. Reference[8] also reported variation in concentration of the secondary plant compound in time and space and also among and within plant varieties. Furthermo re a positive and strong significant correlation $(\mathrm{r}=0.81, \mathrm{P}=0.001)$ was recorded between percentage incidence and severity score with respect to variety during the two cropping season.

Pertaining to time of observation, percentage incidence was significantly $(\mathrm{P}<0.05)$ higher at 9MAP across the two cropping seasons followed by 6MAP, 3MAP whilst zero incidence was recorded for 12 MAP (Table 2). The reason for thehigher incidence at $6 \mathrm{MAP}$ and $9 \mathrm{MAP}$ could be related to the life cycle of the grasshopper. This insect lay its eggs in March/April. These eggs hatch in late September to early November and the late nymphs and adults enter the cassava field later in the dry season between January to March as reported by[15].

Percentage incidence ranged from moderate ((40- $48.9 \%)$ to low $(0-11,9)$ across the two cropping season. Generally, percentage incidence was higher during 2010/2011 cropping season compared to 2009/2011 cropping season.

The interaction between variety and observation time with respect to percentage incidence during 2009/2011 and 2010/2011 was also significant $(P<0.05)$.

The entire document should be in Times New Roman. The font sizes to be used are specified in Table 1.

The size of a lower-case "j" will give the point size by measuring the distance from the top of an ascender to the bottom of a descender.

Table 1. Mean Percentage Incidence With Respect to Cassava Variety

\begin{tabular}{ccc}
\hline & \multicolumn{2}{c}{ Percentage incidence } \\
\cline { 2 - 3 } Variety & Season & $\begin{array}{c}\text { 2009/2010 cropping } \\
\text { season }\end{array}$ \\
\hline Slicass 1 05-21 & $7.64 \mathrm{j}$ & $24.75 \mathrm{bc}$ \\
VT 05-02 & $19.09 \mathrm{c}$ & $10.42 \mathrm{c}$ \\
Slicass 2 & $15.83 \mathrm{cdef}$ & $20.33 \mathrm{bc}$ \\
SN 05-22 & $17.43 \mathrm{~cd}$ & $29.66 \mathrm{abc}$ \\
Slicass 1 05-14 & $8.91 \mathrm{i}$ & $33.9 \mathrm{ab}$ \\
Slicass 2 05-17 & $14.83 \mathrm{cdef}$ & $20.42 \mathrm{bc}$ \\
Slicass 5 & $11.91 \mathrm{~h}$ & $14.75 \mathrm{bc}$ \\
VT 05-07 & $22.36 \mathrm{~b}$ & $18.78 \mathrm{bc}$ \\
SN 05-41 & $14.33 \mathrm{defgh}$ & $16.78 \mathrm{bc}$ \\
Slicass 1 05-05 & $17.26 \mathrm{~cd}$ & $24.10 \mathrm{bc}$ \\
97/3202-05-04 & $16.15 \mathrm{cde}$ & $33.41 \mathrm{ab}$ \\
Slicsaa 4 & $27.16 \mathrm{a}$ & $18.75 \mathrm{bc}$ \\
Slicass 1 05-42 & $16.87 \mathrm{~cd}$ & $33.417 \mathrm{abc}$ \\
SN 05-17 & $16.91 \mathrm{~cd}$ & $24.75 \mathrm{bc}$ \\
Slicass 1 & $14.77 \mathrm{defg}$ & $30.41 \mathrm{abc}$ \\
Local & $29.76 \mathrm{a}$ & $45.16 \mathrm{a}$ \\
97/0057-05-04 & $16.15 \mathrm{cde}$ & $17.67 \mathrm{bc}$ \\
Slicass 6 & $11.53 \mathrm{hi}$ & $27.08 \mathrm{abc}$ \\
97/0057-05-01 & $11.42 \mathrm{ghi}$ & $18.50 \mathrm{bc}$ \\
Slicass 2 05-13 & $12.68 \mathrm{fg}$ & $26.25 \mathrm{abc}$ \\
\hline
\end{tabular}

Means in column with the same letter are not significantly different at $\mathrm{P}>$ 0.05 (SNK)

Table 2. Mean Percentage Incidence With Respect to Observation Time

\begin{tabular}{|c|c|c|}
\hline \multirow{2}{*}{$\begin{array}{l}\text { Observation } \\
\text { time (MAP) }\end{array}$} & \multicolumn{2}{|c|}{ Percentage incidence } \\
\hline & $\begin{array}{c}2009 / 2010 \\
\text { cropping season }\end{array}$ & $\begin{array}{c}2010 / 2011 \text { cropping } \\
\text { season }\end{array}$ \\
\hline 3 & $14.26 \mathrm{~b}$ & $11.19 \mathrm{~b}$ \\
\hline 6 & $40.53 \mathrm{a}$ & $48.93 \mathrm{a}$ \\
\hline 9 & $44.18 \mathrm{a}$ & $52.79 \mathrm{a}$ \\
\hline 12 & $0.00 \mathrm{c}$ & $0.00 \mathrm{c}$ \\
\hline
\end{tabular}

Means in column with the same letter are not significantly different at $\mathrm{P}>$ 0.05 (SNK)

\subsection{Severity Score}

Also significant differences $(\mathrm{p}<0.05)$ were recorded in severity score with respect cassava variety during 2009/2010 and 2010/2011 cropping season with 2010/ 2011 recording the highest score (1.55) compared to 2009/2010 (1.42) cropping seas on (Table 3 ). The reason for the slightly higher reported severity score in 2010/2011 cropping season compared to 2009/2010 cropping season could be due to differences in the rainfall pattern between the two cropping seasons. The rains came earlier during the 2009/2010 cropping season which kill most of the grasshoppers as rain is one of the natural mortality factor for grasshoppers[16]. This early rain also causes the cassava plant to recover quickly from the defoliation effect of the grasshoppers.

During 2009/2010 cropping season severity score ranged from moderate (1.4-1.8) to low (1.1-1.3). Six varieties Slicass 5, VT 05-02, Slicass 4, 97/0057-05-04, 97/0057-05-01 and Slicass 6 recorded severity scores of 
between 1 and 1.2 (Table 3 ). These varieties could be regarded as less susceptible to the grasshoppers as such a low severity score does not lead to any economic damage. For 2010/2011 cropping seas on, severity score also ranged from moderate (1.4-2.24) to low (1-1.3).A lso, in the 2010/2011 cropping season, five varieties: Slicass 5, Slicass 1 05-21, 97/0057-05-04, 97/0057-05-01 and slicass 6 registered severity scores of between 1-1.2. These varieties could also be regarded as less susceptible to the grasshoppers (Table 3).

With regard to observation time, significant diffe rences $(\mathrm{P}$ $<0.05$ ) were also recorded in severity scores during the two cropping seasons with 2010/2011 cropping season again registering a slightly higher severity score (1.62) co mpared to $2009 / 2010$ cropping seas on (1.44) (Table 4).

Table 3. Mean Severity Score With Respect to Cassava Variety

\begin{tabular}{ccc}
\hline & \multicolumn{2}{c}{ Severity score } \\
\cline { 2 - 3 } Variety & $\begin{array}{c}\text { 2009/2010 cropping } \\
\text { season }\end{array}$ & $\begin{array}{c}2010 / 201 \mathrm{cropping} \\
\text { season }\end{array}$ \\
\hline Slicass 1 05-21 & $1.37 \mathrm{abc}$ & $1.71 \mathrm{f}$ \\
VT 05-02 & $1.08 \mathrm{abc}$ & $1.48 \mathrm{jk}$ \\
Slicass 2 & $1.43 \mathrm{abc}$ & $1.57 \mathrm{hi}$ \\
SN 05-22 & $1.63 \mathrm{ab}$ & $1.76 \mathrm{e}$ \\
Slicass 1 05-14 & $1.65 \mathrm{ab}$ & $1.91 \mathrm{bc}$ \\
Slicass 2 05-17 & $1.46 \mathrm{abc}$ & $1.51 \mathrm{gh}$ \\
Slicass 5 & $1.26 \mathrm{bc}$ & $1.23 \mathrm{~lm}$ \\
VT 05-07 & $1.33 \mathrm{abc}$ & $1.63 \mathrm{gh}$ \\
SN 05-41 & $1.42 \mathrm{abc}$ & $1.85 \mathrm{~cd}$ \\
Slicass 1 05-05 & $1.52 \mathrm{abc}$ & $2.24 \mathrm{a}$ \\
97/3202-05-04 & $1.8 \mathrm{a}$ & $1.95 \mathrm{~b}$ \\
Slicsaa 4 & $1.19 \mathrm{bc}$ & $1.5 \mathrm{ij}$ \\
Slicass 1 05-42 & $1.55 \mathrm{abc}$ & $1.91 \mathrm{bc}$ \\
SN 05-17 & $1.41 \mathrm{abc}$ & $1.49 \mathrm{j}$ \\
Slicass 1 & $1.66 \mathrm{ab}$ & $1.67 \mathrm{fg}$ \\
Local & $1.69 \mathrm{ab}$ & $1.80 \mathrm{de}$ \\
97/0057-05-04 & $1.28 \mathrm{bc}$ & 1.261 \\
Slicass 6 & $1.24 \mathrm{bc}$ & $1.17 \mathrm{~m}$ \\
97/0057-05-01 & $1.24 \mathrm{bc}$ & $1.0 \mathrm{~m}$ \\
Slicass 2 05-13 & $1.61 \mathrm{ab}$ & $1.43 \mathrm{k}$ \\
\hline
\end{tabular}

Means in column with the same letter are not significantly different at $\mathrm{P}>0.05$ (SNK); Severity score: $1=0-20 \%$ of foliag e consumed, $2=21-40 \%$ of foliage consumed, $3=41-60 \%$ of foliage consum ed, $4=61-80 \%$ of foliage consumed and $5=81-100 \%$ of foliag e consumed

Table 4. Mean Severity Score With Respect to Observation Time

\begin{tabular}{llll}
\hline \multirow{2}{*}{$\begin{array}{l}\text { Observation } \\
\text { time (MAP) }\end{array}$} & \multicolumn{2}{l}{ Severity score } & \\
\cline { 2 - 4 } & $2009 / 2010$ cropping & $2010 / 2011$ & cropping \\
3 & season & season & \\
6 & $1.09 \mathrm{c}$ & $1.19 \mathrm{c}$ & \\
9 & $1.94 \mathrm{~b}$ & $2.02 \mathrm{~b}$ & \\
\hline 12 & $2.06 \mathrm{a}$ & $2.37 \mathrm{a}$ & \\
\hline
\end{tabular}

Mean $\mathrm{s}$ in column with the same letter are not significantly different at $\mathrm{P}>$ 0.05 (SNK); Severity score: $1=0-20 \%$ of foliage consumed, $2=21-40 \%$ of foliage consumed, $3=41-60 \%$ of foliag e consumed, $4=61-80 \%$ of foliage consumed and $5=81-100 \%$ of foliage consumed

In addition, severity score was higher at 9MAP during to two cropping seasons followed by 6 MAP, 3 MAP and 12 MAP. The reason for the slightly high severity at $6 \mathrm{MAP}$ and 9MAP could be related to the fact at this stage of development of the plant, the grasshoppers would have developed to the late instars or adult stage which causes most destruction in the cassava field. The above observation is in accordance with[9] who reported that the older larvae and adults cause more damage to cassava. The reported low severity at 3MAP is due to the fact that at this stage of development, only the early nymphs will be present which uses the cassava as a roosting site[15] rather than as food. This early nymphs will not feed of cassava because of its high cynogenic content. This observation is in agreement with the findings of[9]. These authors reported that the first and second instars of grasshopper will prefer to die rather than feed on cassava. Also most of the early nymphs were found on alternate host within or outside the cas sava field.

Furthermore, significant interactions $(\mathrm{P}<0.05)$ were also observed between variety and time of observation with respect to severity score for the two cropping seasons.

\subsection{Weight of Tuber}

Significant differences were also recorded in tuber weight with respect to variety during $2009 / 2010$ cropping seas on (P $=0.0001, \mathrm{~F}=4.70)$ and during the $2010 / 2011$ cropping season $(F=5.97, P=0.0001)$. However, significant differences $(\mathrm{P}>0.05)$ were not recorded in tuber weight with respect to variety across cropping season even though a slightly higher weight $(15.70 \mathrm{~kg})$ was recorded during 2009/2010 cropping seas on compared to 2010/2011 (15.20 $\mathrm{kg}$ ) cropping season (Table 5). Possible reason for this observation could be due to the early rains during the 2009/2010 cropping season which kills most of the grasshoppers and causes the plant to recover quickly from the defoliation effect of the grasshoppers.

During the 2009/2010 cropping season, Slicass2 05-07 recorded the highest tuber weight (28.80) out yield ing the released varieties (Slicass 4 (14.44), Slicass 5 (9.33), Slicass 1 (10.65), Slicass 2 (17.67) and slicass 6 (18.16) ) ( Table 5). For 2010/2011 cropping season, 97/0057-05-01 reg istered the highest tuber weight (26.33) again out yielding the released varieties. In addition, a positive and strong significant correlation $(\mathrm{r}=0.78, \mathrm{P}=0.0001)$ was recorded between tuber weight and number with respect to variety during the two cropping season.

Similarly, tuber weight was also significantly higher $(\mathrm{P}<$ 0.05 ) with respect to treatment during the 2009/2010 cropping season compared to 2010/ 2011 cropping season.Generally, tuber weight was significantly $(\mathrm{P}<0.05)$ higher in the protected plot compared to the unprotected plot across the two cropping season (Table 6). In the unprotected plot, the grasshopper fed on the foliage and stem thus reducing the leaf or photosynthetic rate. Studies have shown that pests that attack crop over prolong periods (3-5months) causes severe root yield reduction[17] as a result of their feeding on leaf cell fluid and the subsequent decrease in photosynthesis. Also, it is reported that for each defoliation that occurs as a result of feeding by grasshoppers, the plant will re-direct their assimilate towards regeneration of new leaves[18],[19]. This re-growth of new leaves after pest 
attack involves depletion of roots and stem reserves[20] which may decrease yield and number of tubers and also increases the susceptibility of the root to rot.

In addition, significant interactions were also recorded between cassava variety and treatment with respect to tuber weight during the $2009 / 2010$ cropping seas on $(\mathrm{F}=3.73$, $\mathrm{P}=$ $0.04)$ and $2010 / 2011$ cropping season $(F=6.53, P=0.004)$.

Table 5. Mean Weight of Tuber With Respect to Cassava Variety

\begin{tabular}{ccc}
\hline & \multicolumn{2}{c}{ Weight of storage root $(\mathrm{Kg})$} \\
\cline { 2 - 3 } Variety & $\begin{array}{c}\text { 2009/2010 cropping } \\
\text { season }\end{array}$ & $\begin{array}{c}2010 / 2011 \mathrm{cropping} \\
\text { season }\end{array}$ \\
\hline Slicass 1 05-21 & $16.83 \mathrm{cdefg}$ & $11.92 \mathrm{def}$ \\
VT 05-02 & $18.83 \mathrm{bcde}$ & $21.08 \mathrm{abc}$ \\
Slicass 2 & $17.67 \mathrm{bcdef}$ & $16.33 \mathrm{bcdef}$ \\
SN 05-22 & $17.83 \mathrm{bcdef}$ & $15.83 \mathrm{bcdef}$ \\
Slicass 1 05-14 & $25.16 \mathrm{ab}$ & $6.76 \mathrm{f}$ \\
Slicass 2 05-17 & $28.83 \mathrm{a}$ & $15.58 \mathrm{bcdef}$ \\
Slicass 5 & $9.33 \mathrm{~g}$ & $19.08 \mathrm{abcd}$ \\
VT 05-07 & $15.50 \mathrm{defg}$ & $13.08 \mathrm{bcdef}$ \\
SN 05-41 & $20.16 \mathrm{bcd}$ & $16.58 \mathrm{bcdef}$ \\
Slicass 1 05-05 & $11.58 \mathrm{efg}$ & $22.01 \mathrm{abc}$ \\
97/3202-05-04 & $10.50 \mathrm{fg}$ & $21.17 \mathrm{abc}$ \\
Slicsaa 4 & $14.33 \mathrm{defg}$ & $22.83 \mathrm{ab}$ \\
Slicass 1 05-42 & $17.00 \mathrm{defg}$ & $13.25 \mathrm{bcdef}$ \\
SN 05-17 & $16.67 \mathrm{cdefg}$ & $14.58 \mathrm{bcdef}$ \\
Slicass 1 & $10.66 \mathrm{fg}$ & $12.50 \mathrm{bcdef}$ \\
Local & $19.50 \mathrm{bcdef}$ & $8.50 \mathrm{ef}$ \\
97/0057-05-04 & $24.66 \mathrm{abc}$ & $26.33 \mathrm{a}$ \\
Slicass 6 & $18.16 \mathrm{cdef}$ & $20.167 \mathrm{abc}$ \\
97/0057-05-01 & $16.83 \mathrm{cdef}$ & $18.08 \mathrm{abcde}$ \\
Slicass 2 05-13 & $24.16 \mathrm{abc}$ & $9.17 \mathrm{def}$ \\
\hline
\end{tabular}

Means in column with the same letter are not significantly different at $\mathrm{P}>0.05$ (SNK)

Table 6. Mean Weight of Tuber With Respect to Treatment

\begin{tabular}{ccc}
\hline \multirow{2}{*}{ Treatment } & \multicolumn{2}{c}{ Weight of storage root $(\mathrm{kg})$} \\
\cline { 2 - 3 } & $2009 / 2010$ & $2010 / 2011$ cropping \\
& cropping season & season \\
Protected & $21.02 \mathrm{a}$ & $17.86 \mathrm{a}$ \\
Unprotected & $14.51 \mathrm{~b}$ & $14.66 \mathrm{~b}$ \\
\hline
\end{tabular}

Means in column with the same letter are not significantly different at $\mathrm{P}>0.05$ (SNK)

\subsection{Number of Tubers}

The number of tuber also varies significantly across variety during the $2009 / 2010$ cropping season $(P=0.009, \mathrm{~F}$ $=276)$, and $2010 / 2011$ cropping season $(\mathrm{F}=5.12, \mathrm{P}=$ 0.0001 ) (Table 7). During the $2009 / 2010$ cropping season, SN 05-41 (77.62) and Slicass $205-05$ (78.50) recorded the highest tuber number outnumbering the release varieties (Slicass 5 (51.83), Slicass 2 (48.83), Slicass 4 (45.17), Slicass $6(57.33)$ and slicass 1 (26.17)). The least number of tuber was recorded by Slicass 1 which is one of our release varieties (Table 7). On the other hand, during the 2010/2011 cropping seas on, Sicass 1 05-0 5 (93.83) recorded the highest number of tuber again outnumbering the released varieties. Generally, the nu mber of tubers produced was higher during the 2010/ 2011 cropping season compared to 2009/2010 cropping season.

With respect to treatment, number of tubers was also significantly higher during the 2010/2011 cropping seas on $(\mathrm{P}=0.003, \mathrm{~F}=9.06)$ compared to $2009 / 2010$ cropping season $(\mathrm{P}=0.002, \mathrm{~F}=15.09)$ (Table 8). During the two cropping season, the protected plot registered the highest number of tuber compared to the unprotected plot. The reason being that the unprotected plot was defoliated to a certain degree resulting in the reduction in the photosynthetic rate and subsequent reduction in the number of tuber and yield[17].

Table 7. Mean number of tuber with respect to cassava variety

\begin{tabular}{ccc}
\hline \multirow{2}{*}{ Variety } & \multicolumn{2}{c}{ Number of storage root } \\
\cline { 2 - 3 } & $\begin{array}{c}\text { 2009/2010 cropping } \\
\text { season }\end{array}$ & $\begin{array}{c}2010 / 2011 \text { cropping } \\
\text { season }\end{array}$ \\
\hline Slicass 1 05-21 & 53.50 abcd & $58.50 \mathrm{bcd}$ \\
\hline VT 05-02 & $45.33 \mathrm{bcde}$ & 75.0 \\
\hline Slicass 2 & $48.83 \mathrm{bcde}$ & $54.50 \mathrm{bcd}$ \\
\hline SN 05-22 & $62.00 \mathrm{abcd}$ & $74.83 \mathrm{abc}$ \\
\hline Slicass 1 05-14 & $64.50 \mathrm{abc}$ & $37.00 \mathrm{~d}$ \\
\hline Slicass 2 05-17 & $78.50 \mathrm{a}$ & $73.17 \mathrm{abc}$ \\
\hline Slicass 5 & $51.83 \mathrm{abcd}$ & $66.50 \mathrm{abcd}$ \\
\hline VT 05-07 & $51.83 \mathrm{abcd}$ & $70.00 \mathrm{abcd}$ \\
\hline SN 05-41 & $77.62 \mathrm{a}$ & $64.50 \mathrm{abcd}$ \\
\hline Slicass 1 05-05 & $36.33 \mathrm{de}$ & $93.83 \mathrm{a}$ \\
\hline 97/3202-05-04 & $47.67 \mathrm{bcde}$ & $75.33 \mathrm{abc}$ \\
\hline Slicsaa 4 & $45.17 \mathrm{bcde}$ & $87.33 \mathrm{ab}$ \\
\hline Slicass 1 05-42 & $54.83 \mathrm{abcd}$ & $80 \mathrm{abc}$ \\
\hline SN 05-17 & $56.33 \mathrm{abcd}$ & $57.33 \mathrm{bcd}$ \\
\hline Slicass 1 & $26.67 \mathrm{e}$ & $51.33 \mathrm{~cd}$ \\
\hline Local & $68.33 \mathrm{de}$ & $39.33 \mathrm{~d}$ \\
\hline 97/0057-05-04 & $71.33 \mathrm{ab}$ & $82.00 \mathrm{abc}$ \\
\hline Slicass 6 & $57.33 \mathrm{abcd}$ & $58.50 \mathrm{bcd}$ \\
\hline 97/0057-05-01 & $42.00 \mathrm{cde}$ & $75.83 \mathrm{abc}$ \\
\hline Slicass 2 05-13 & $55.33 \mathrm{abcde}$ & $38.33 \mathrm{~d}$ \\
\hline & &
\end{tabular}

Means in column with the same letter are not significantly different at $\mathrm{P}>0.05$ (SNK)

Table 8. Mean number of tuber with respect to treatment

\begin{tabular}{ccc}
\hline \multirow{2}{*}{ Treatment } & \multicolumn{2}{c}{ Number of storage root } \\
\cline { 2 - 3 } & $2009 / 2010$ & $2010 / 2011$ cropping \\
cropping season & season \\
Protected & $61.67 \mathrm{a}$ & $70.50 \mathrm{a}$ \\
Unprotected & $47.92 \mathrm{~b}$ & $60.92 \mathrm{~b}$ \\
\hline
\end{tabular}

Means in column with the same letter are not significantly different at $\mathrm{P}>0.05$ (SNK)

In addition, the interaction between cassava variety and treatment with respect to the number of tuber was significant ( $F=5.63, P=0.003$ ) during the $2009 / 2010$ cropping season; indicating that the number of tuber produced during the 
cropping season depends on both the cassava variety and treatment. However, the interaction between variety and treatment with respect to tuber number was not significant ( $\mathrm{P}$ $=0.09, \mathrm{~F}=1.4$ ) during $2010 / 2011$ cropping season.

\section{Conclusions}

Results from this research suggest that on the whole, tuber weight and number were higher in the protected plot compared to the unprotected plot during the two cropping seasons. Hence, protecting cassava field from grasshopper infestation may increase yield, number of tubers and invariably the production of good quality planting material that is resistance to grasshopper attack.

\section{ACKNOWLEDGEMENTS}

This work was supported by funding from the Sierra Leone Agricultural Research Institute, Njala.

\section{REFERENCES}

[1] Theiberge, R.L. Common African Pests and Diseases of Cassava, Yam, Sweet potato and Cocoyam. IITA, Ibadan, Nigeria. 108pp, 1985.

[2] Yaninek, J.S. Cassava plant protection in Africa. In: Proceedings of the Fifth. Triennial Symposium of the International Society for Tropical Root Crops-Africa Branch, October, 1991 Accra, Ghana. Ofori, F. and Hahn, S.K. (Eds.), pp.26-34. IIT A, Ibadan, Nigeria. 1994.

[3] Modder, W. W. The attraction of Zonocerus variegatus (L) Orthoptera: Pygomorphidae) to the weed Chromolaena odorata and associated feeding behaviour. Bull. Entomol. Res. 74: $239-247,1984$

[4] Lecoq, M. Le probleme sauteriaux en Afrique soudano-sahelienne: A gronomic Tropical 33:3, 1978.

[5] Harris, J.R. Defoliation and consequent crop loss in cassava caused by grasshopper Zonocerus variegatus in Southern Nigeria. Bulletin of Entomological Research. 70,151-163, 1980.

[6] Mulkern G. B. Food selection by grasshoppers. Annu. Rev. Entomol. 12::59-78, 1967.

[7] Isley F. B. Correlation between mandibular morphology and food specificity in grasshoppers. Ann. Entomol. Soc. Am. $37:: 47-67,1944$.
[8] Bernays, E. A., Chapman, R.F. Plant chemistry and acridoid feeding behaviour. Ann. Proc. Phytoch. Soc. 15: 99-141, 1978.

[9] Bernays, E. A, Chapman, R. F, Leather, E. M, McCaffery, A. R., Modder, W. W .D. The relationship of Zonocerus variegatus with cassava: Bulletin of Entomological Research 67:391-404, 1977.

[10] De Pointi, O. M. B. Romanow, L. R . Berlinger, M. J. White fly plant relationship: Plant resistance, 91-106 pp. In: Whiteflies: their bionomics, pest status and management. Gerling, D. (ed), Intercept Ltd. Andover, 1990.

[11] Odell, R.T., Dijkerman, J.C., Van Vuure, W., Melsted, S.W., Beavers, A.H., Sutton, P.M., Kurtz, L.T., Micdema, R. Characteristics, classification and adaptation of soil in selected areas in Sierra Leone, West Africa. Bulletin 748. Agricultural Experiment Station, College of Agriculture, University of Illinois at Urban - Champaign. Bulletin 4, Njala University College, University of Sierra Leone, 1974.

[12] Capinera J.L. Host-plant selection by Schistocerca americana (Orthoptera: Acrididae). Environ. Entomol. 22::127-133, 1993.

[13] SAS Institute. The SAS system for Windows. Release 8.1. Cary. NU. USA, 2001.

[14] Swain, T. Plant and animal coevolution: A synoptic view of the Paleozoic and Mesozoic. Ann. Proc. Phytoch. Soc. 15:319, 1963.

[15] Bernays, E.A, Chapman, R. F., Cook, A.G., Page, W.W. Food plant in the survival and development of Zonocerus variegatus Acarida 4: 33-46, 1975.

[16] Chapman, R.F., Page, W.W. Factors affecting the mortality of the grasshopper, Zonocerus variegatus, in Southern Nigeria. Journal of Animal Ecology 48:271-288, 1979.

[17] Bellotti, A.C, Brown, A.R, Arias, B., Castillo, J.A., Guerrero, J.M. Origin and management of neotropical cassava arthropod pests Ari. Crop. Sci J. 24: 407-17,1994.

[18] Evans, H.E. Insect Biology. Andison-Wesley publishing Company, London, 1984.

[19] Welter, S. C. Response of plant to insect: Eco-physiological insights. In: International Crop Science I. Based on the international crop science congress, Iowa, 14-22 July 1993. Crop Science Society of America, Inc., Winsconsin U.S.A pp 773-778, 1993.

[20] Schulthess, F., Baumgirtner, J. U., Delucchi, V., Gutierrez, A. P. The influence of cassava mealy bug on yield formation of cassava. Journal of Applied Entomology 111: 155-165, 1991. 